\title{
Divergent functions of angiotensin II receptor isoforms in the brain
}

\author{
Robin L. Davisson, ${ }^{1}$ Michael I. Oliverio, ${ }^{2}$ Thomas M. Coffman, ${ }^{2}$ and Curt D. Sigmund ${ }^{1}$ \\ ${ }^{1}$ Department of Internal Medicine and Department of Physiology and Biophysics, \\ The University of Iowa, Iowa City, Iowa, USA \\ ${ }^{2}$ Division of Nephrology, Department of Medicine, Duke University Medical Center, Durham, North Carolina, USA \\ Address correspondence to: Robin L. Davisson, Department of Anatomy and Cell Biology, \\ The University of Iowa, Iowa City, Iowa 52242, USA. Phone: (319) 335-8094; Fax: (319) 335-7198; \\ E-mail: robin-davisson@uiowa.edu.
}

Received for publication April 4, 2000, and accepted in revised form May 12, 2000. The renin-angiotensin system (RAS) plays a critical role in cardiovascular and fluid homeostasis.
The major biologically active peptide of the RAS is angiotensin $\mathrm{II}$, which acts through $\mathrm{G}$
protein-coupled receptors of two pharmacological classes, $\mathrm{AT}_{1}$ and $\mathrm{AT}_{2} . \mathrm{AT}_{1}$ receptors, expressed
in brain and peripheral tissues, mediate most classically recognized actions of the RAS, including
blood pressure homeostasis and regulation of drinking and water balance. In rodents, two highly
homologous $\mathrm{AT}_{1}$ receptor isoforms, termed $\mathrm{AT}_{1 \mathrm{~A}}$ and $\mathrm{AT}_{1 \mathrm{~B}}$ receptors, are expressed at different lev-
els in major forebrain cardiovascular and fluid regulatory centers, with $\mathrm{AT}_{1 \mathrm{~A}}$ expression generally
exceeding $\mathrm{AT}_{1 \mathrm{~B}}$ expression, but the relative contributions of these receptor subtypes to central
angiotensin II responses are not known. We used gene targeting in combination with a unique sys-
tem for maintaining catheters in the cerebral ventricles of conscious mice to test whether there are
differential roles for $\mathrm{AT}_{1 \mathrm{~A}}$ and $\mathrm{AT}_{1 \mathrm{~B}}$ receptors in responses elicited by angiotensin II in the brain.
Here we show that the blood pressure increase elicited by centrally administered angiotensin II can
be selectively ascribed to the $\mathrm{AT}_{1 \mathrm{~A}}$ receptor. However, the drinking response requires the presence
of $\mathrm{AT}_{1 \mathrm{~B}}$ receptors. To our knowledge, this is the first demonstration of a primary and nonredundant
physiological function for $\mathrm{AT}_{1 \mathrm{~B}}$ receptors.

J. Clin. Invest. 106:103-106 (2000).

\section{Introduction}

The renin angiotensin system (RAS) plays a critical role in cardiovascular and fluid homeostasis. In addition to its importance in regulating normal physiology, enhanced activity or dysregulation of the RAS can lead to maladaptive responses and significant cardiovascular disease. The RAS is an ancient system that is present in lower organisms including amphibians, and many of its features have been conserved across evolution. The major biologically active peptide of the RAS is angiotensin II, and its major actions are mediated by $\mathrm{G}$ protein-coupled angiotensin receptors. These receptors can be divided into two pharmacological classes, $\mathrm{AT}_{1}$ and $\mathrm{AT}_{2}(1)$. Most of the classically recognized actions of the RAS in fluid and blood pressure homeostasis are mediated by $\mathrm{AT}_{1}$ receptors. $\mathrm{AT}_{1}$ receptors are expressed in brain and peripheral tissues. The central nervous system (CNS) receptors play a key role in blood pressure regulation and in regulation of drinking and water balance (2).

The discovery of two $\mathrm{AT}_{1}$ receptor isoforms in rats and mice, termed $\mathrm{AT}_{1 \mathrm{~A}}$ and $\mathrm{AT}_{1 \mathrm{~B}}$ receptors, uncovered an additional level of complexity of the system (3-5). These receptors are highly homologous with indistinguishable binding profiles, but are products of distinct genes (Agtr1a and Agtr1b) that are differentially expressed and regulated (6-8). Although a single report has suggested the existence of $\mathrm{AT}_{1 \mathrm{~B}}$ receptors in humans (9), most investigators believe that humans have only a single $\mathrm{AT}_{1}$ receptor gene. Despite this apparent genetic difference, the physiological actions of $\mathrm{AT}_{1}$ receptors in humans and rodents are virtually identical. Because pharmacological $\mathrm{AT}_{1}$ receptor antagonists cause equivalent inhibition of both $\mathrm{AT}_{1}$ isoforms, the relative physiological roles of $\mathrm{AT}_{1 \mathrm{~A}}$ and $\mathrm{AT}_{1 \mathrm{~B}}$ and their relationship to human $\mathrm{AT}_{1}$ receptor functions have been difficult to identify. Recent gene-targeting experiments have clarified the relative role of the $\mathrm{AT}_{1 \mathrm{~A}}$ and $\mathrm{AT}_{1 \mathrm{~B}}$ receptors in the periphery, demonstrating a predominant role for $\mathrm{AT}_{1 \mathrm{~A}}$ receptors in regulation of vascular tone $(10,11)$. In the brain as in the periphery, expression of $\mathrm{AT}_{1 \mathrm{~A}}$ exceeds that of $\mathrm{AT}_{1 \mathrm{~B}}$, with the exception of the pituitary gland, where $\mathrm{AT}_{1 \mathrm{~B}}$ expression predominates (12-14). $\mathrm{AT}_{1 \mathrm{~A}}$ expression is especially prominent in major forebrain cardiovascular and fluid regulatory centers (12). $\mathrm{AT}_{1 \mathrm{~B}}$ expression is highest in the anterior pituitary (12-14). However, the relative contributions of these $\mathrm{AT}_{1}$ receptor subtypes to central angiotensin II responses are not known. We used gene targeting in combination with a unique system for maintaining catheters in the cerebral ventricles of conscious mice to test whether there are differential roles for $\mathrm{AT}_{1 \mathrm{~A}}$ and $\mathrm{AT}_{1 \mathrm{~B}}$ receptors in responses elicited by angiotensin II in the CNS. 


\section{Methods}

Animals. Mice with targeted deletions of the $\mathrm{AT}_{1 \mathrm{~A}}$ $\left(\right.$ Agtr1 $\left.a^{-/-}\right)$or $\mathrm{AT}_{1 \mathrm{~B}}\left(\right.$ Agtr $\left.1 b^{-/-}\right)$receptors were generated using homologous recombination in embryonic stem cells as described previously $(10,15,16)$. Knockout mice were maintained on the original $129 \mathrm{~Sv} / \mathrm{C} 57 \mathrm{Bl}$ hybrid background, and wild-type controls were littermates of each of the respective knockout models. All mice were fed standard mouse chow (LM-485; Teklad Premier Laboratory Diets) and water ad libitum. Care for the mice used in the experiments exceeded the standards set forth by the National Institutes of Health in their guidelines for the care and use of experimental animals. All procedures were approved by the University Animal Care and Use Committee at the University of Iowa.

Surgical procedures. Mice were implanted with intracerebroventricular (ICV) cannulae and carotid arterial catheters for brain microinjection of drugs and for direct measurement of pulsatile and mean arterial pressure (MAP), respectively, as described by us in detail previously (17). All experiments were performed in conscious, freely moving mice. Animals were allowed 4 days' recovery before in vivo testing for proper ICV cannula placement by intraventricular injection of the muscarinic agonist carbachol (50 ng). Carbachol elicits a characteristic pressor and bradycardic response in rodents when injected intraventricularly (17). Mice that did not respond to carbachol were not used in the studies $(n=2)$.

Experimental protocols. Two days after in vivo testing of cannula placement with carbachol, the blood pressure effects of ICV angiotensin II (50, 100, and $200 \mathrm{ng})$ were examined in the home cage following the protocol described previously (10). Mice were allowed 60 minutes' adaptation after connection to recording equipment and insertion of the ICV injector. The volume of each injection was $300 \mathrm{~nL}$. Thirty minutes was allowed before administration of the next dose. The number of drinking episodes was also recorded during the 30 minutes after each dose of angiotensin II. A single drinking episode was defined as the mouse approaching and then drinking from the water tube. Removal of the tongue from the sipper tube defined the end of an episode. This approach was taken because of the difficulty in accurately measuring small quantities of water acutely consumed by mice. The miniature glass burette drinking tube was placed on the home cage before surgery and remained throughout the experiment.

Separate experiments were performed to assess the role of non- $\mathrm{AT}_{1}$ receptors in the dipsogenic action of angiotensin. Studies were carried out as already described here, with mice being allowed 60 minutes' adaptation before ICV injection of the largest dose of angiotensin II (200 ng, $300 \mathrm{~nL})$. The number of drinking episodes were recorded for 30 minutes after injection. The ICV injector was then removed and replaced with one for microinjection of the selective $\mathrm{AT}_{1}$ recep- tor antagonist losartan $(10 \mu \mathrm{g}, 500 \mathrm{~nL})$. Ten minutes later, the ICV angiotensin II injection $(200 \mathrm{ng}, 300 \mathrm{~nL})$ was repeated and drinking behavior was recorded for 30 minutes. The dose and time course for losartan blockade of $\mathrm{AT}_{1}$ receptors has been established in previous studies (17).

\section{Results}

Six days after cannulation of the lateral brain ventricles and the carotid artery in mice with a gene targeted dele-

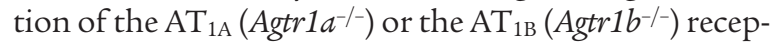
tor or in wild-type littermates, we measured intra-arterial pressures in conscious freely moving mice. MAPs were similar in wild-type $(114 \pm \mathrm{mmHg})$ and Agtr1 $b^{-/-}$ mice $(111 \pm \mathrm{mmHg} ; P>0.05)$. However, basal blood pressure in the Agtr1 $\mathrm{a}^{-/-}$mice $(99 \pm \mathrm{mmHg})$ was significantly lower than that of wild-type controls $(P<0.01)$, confirming a role for the $\mathrm{AT}_{1 \mathrm{~A}}$ receptor in normal maintenance of blood pressure (10).

The vasopressor effect of central angiotensin II has been suggested to be a critical component in both chronic blood pressure regulation and the pathogenesis of hypertension (2). As shown in Figure 1, ICV injection of angiotensin II caused an acute, dose-dependent increase in blood pressure in wild-type mice. This response is identical to that seen in other species (2). The vascular effects of ICV injection of angiotensin II in Agtr $1 b^{-/-}$mice was virtually identical to those seen in controls (Figure 1), suggesting that the $\mathrm{AT}_{1 \mathrm{~B}}$ receptor does not have an essential contribution to this response. By contrast, ICV injection of angiotensin II induced only a very minor increase in blood pressure in Agtrla ${ }^{-/-}$mice (Figure 1). Thus, the CNS actions of angiotensin II to increase blood pressure are primarily mediated by $\mathrm{AT}_{1 \mathrm{~A}}$ receptors.

Along with its effects to raise blood pressure, angiotensin II that is generated in the CNS has potent dipsogenic actions. These effects are believed to stim-

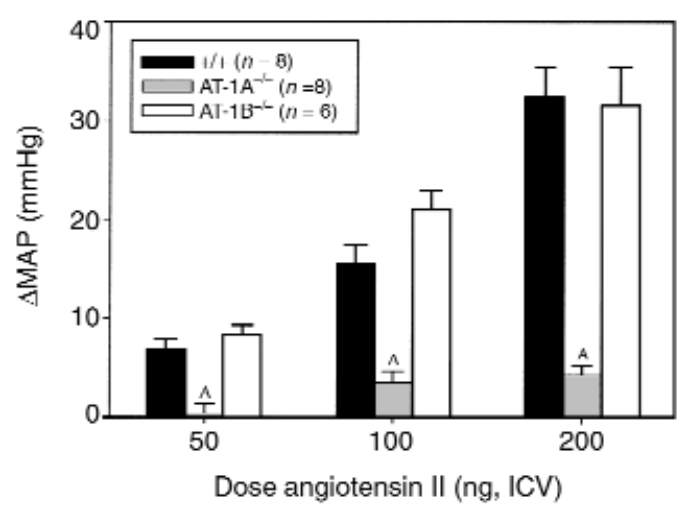

\section{Figure 1}

Blood pressure responses to centrally administered angiotensin II. A summary of the change in MAP $(\mathrm{mmHg})$ elicited by three different doses of angiotensin II (50,100, and $200 \mathrm{ng})$ administered intracerebroventricularly (ICV) in wild-type mice $(+/+)$ and in mice with gene-targeted deletions of $\mathrm{AT}_{1 \mathrm{~A}}\left(\mathrm{AT}^{\left.-1 \mathrm{~A}^{-/-}\right)}\right.$or $\mathrm{AT}_{1 \mathrm{~B}}\left(\mathrm{AT}^{-1 \mathrm{~B}^{-/-}}\right)$ receptors. ${ }^{A} P<0.001$ versus wild-type. 


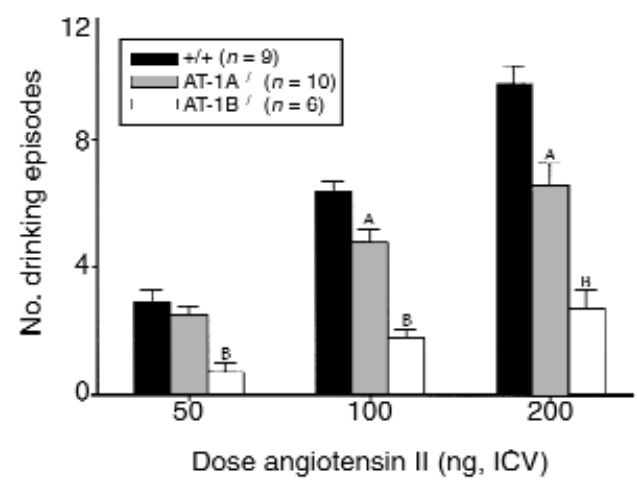

Figure 2

Effects of centrally administered angiotensin II on water drinking. A summary of the number of drinking episodes elicited by ICV angiotensin II $(50,100$, and $200 \mathrm{ng})$ in wild-type mice $(+/+)$ and in mice with gene-targeted deletions of $\mathrm{AT}_{1 \mathrm{~A}}\left(\mathrm{AT}^{\left.-1 \mathrm{~A}^{-/-}\right)}\right.$or $\mathrm{AT}_{1 \mathrm{~B}}(\mathrm{AT}-$ $1 \mathrm{~B}^{-/-}$) receptors. ${ }^{A} P<0.05$ versus wild-type; ${ }^{\mathrm{B} P}<0.001$ versus wildtype and $P<0.01$ versus $\mathrm{AT}^{-1 \mathrm{~B}^{-/}-\text {. }}$

ulate drinking behavior during states of volume depletion (2). As shown in Figure 2, ICV administration of angiotensin II to wild-type mice elicited a robust drinking response that is similar to that reported in many other species (2). We next examined the effects of $\mathrm{AT}_{1}$ receptor gene mutations on the dipsogenic effects of angiotensin II. Compared to wildtype mice, there was a small but statistically significant $(P<0.05)$ reduction in the drinking response to the highest doses of angiotensin $\mathrm{II}$ in the $\mathrm{AT}_{1 \mathrm{~A}}$ receptor-deficient mice. By contrast, in the $\mathrm{AT}_{1 \mathrm{~B}}$-deficient mice, drinking evoked by central angiotensin II was markedly diminished compared with either wild-type $(P<0.001)$ or Agtr1 $a^{-/-}$animals $(P<0.01)$. These data indicate that $\mathrm{AT}_{1 \mathrm{~B}}$ receptors are the primary mediators of the central dipsogenic actions of angiotensin II, whereas $\mathrm{AT}_{1 \mathrm{~A}}$ receptors make only a modest contribution to this response. This is the first demonstration of a primary and nonredundant physiological function of $\mathrm{AT}_{1 \mathrm{~B}}$ receptors.

Most previous studies have suggested that $\mathrm{AT}_{1}$ receptors are responsible for the entire dipsogenic action of angiotensin II. However, a few studies have suggested roles for $\mathrm{AT}_{2}$ and other non- $\mathrm{AT}_{1}$ receptors in these responses (e.g., ref. 18). To test for a contribution of non- $\mathrm{AT}_{1}$ receptors to this response in wild-type mice, and to evaluate whether these responses might be more pronounced in $\mathrm{AT}_{1}$-mutant animals, we examined the effects of losartan, a specific $\mathrm{AT}_{1}$ receptor antagonist with equivalent potency for $\mathrm{AT}_{1 \mathrm{~A}}$ and $\mathrm{AT}_{1 \mathrm{~B}}$ receptors. As shown in Figure 3, the $\mathrm{AT}_{1}$ receptor antagonist completely blocked angiotensin II-induced drinking in wild-type and $\mathrm{AT}_{1 \mathrm{~A}}$ receptor-deficient mice. Likewise, the small residual response in the Agtr $1 b^{-/-}$mice was also abrogated by losartan. These data indicate that in mice, non- $\mathrm{AT}_{1}$ receptors play no significant role in the stimulation of drinking by angiotensin II.

\section{Discussion}

Our data show that $\mathrm{AT}_{1 \mathrm{~A}}$ and $\mathrm{AT}_{1 \mathrm{~B}}$ receptors have distinct functions in mediating the central actions of angiotensin II. The blood pressure effects are produced exclusively by activation of $\mathrm{AT}_{1 \mathrm{~A}}$ receptors, whereas $\mathrm{AT}_{1 \mathrm{~B}}$ receptors are responsible for a major portion of the drinking response. The mechanism of this functional divergence between these two highly homologous receptors in the brain remains to be determined. Because the ligand specificities and signal-effector coupling are virtually identical for the two receptors, differential localization and/or unique neural circuitry for $\mathrm{AT}_{1 \mathrm{~A}}$ and $\mathrm{AT}_{1 \mathrm{~B}}$ in the brain may explain these differential functions. Although the coding regions for these receptors are nearly identical, their upstream sequences, including regulatory sequences, have little identity. Moreover, differential regulation of expression of the two receptors in peripheral tissues has been reported previously (4-8).

The physiological functions of the RAS are very similar in rodents and humans. Although there is a report suggesting that $\mathrm{AT}_{1 \mathrm{~B}}$ receptors might also exist in humans (9), to our knowledge this has not been independently confirmed. Our findings raise the question of whether the separate functions mediated by brain $\mathrm{AT}_{1 \mathrm{~A}}$ and $\mathrm{AT}_{1 \mathrm{~B}}$ receptors in lower mammals have been merged and are provided by a single receptor in humans. If so, it is interesting that the global actions of $\mathrm{AT}_{1}$ receptors in the CNS are very similar in humans and rodents. Alternatively, there may be a yet unidentified angiotensin receptor in human brain that is important in blood pressure and/or body fluid regulation. Nonetheless, this divergence of function between $\mathrm{AT}_{1 \mathrm{~A}}$ and $\mathrm{AT}_{1 \mathrm{~B}}$ receptors in brain provides a scenario to identify separately the more distal signals involved in vasomotor and drinking responses stimulated by angiotensin II.

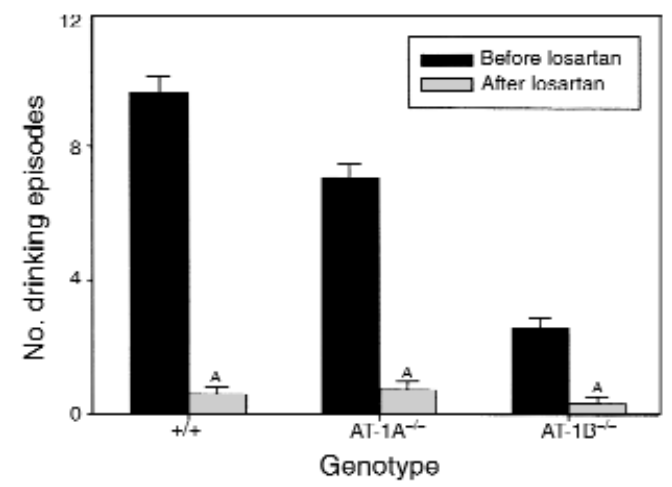

Figure 3

Effect of the specific AT1 receptor antagonist losartan on central angiotensin-II-induced drinking. A summary of the water drinking effects elicited by ICV angiotensin II (200 ng) before and after ICV administration of losartan $(10 \mu \mathrm{g})$ in wild-type mice $(+/+)$ and in mice with gene-targeted deletions of $\mathrm{AT}_{1 \mathrm{~A}}\left(\mathrm{AT}^{\left.-1 \mathrm{~A}^{-/-}\right)}\right.$or $\mathrm{AT}_{1 \mathrm{~B}}$

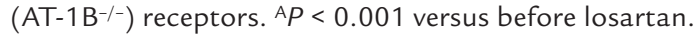




\section{Acknowledgments}

The authors thank T.G. Beltz for help with ICV cannulation, and A.K. Johnson for the generous gift of the losartan.

1. Timmermans, P., et al. 1993. Angiotensin II receptors and angiotensin II receptor antagonists. Pharmacol. Rev. 45:205-251.

2. Phillips, M. 1987. Function of angiotensin in the central nervous system. Annu. Rev. Physiol. 49:413-435.

3. Sandberg, K., Ji, H., Clark, A., Shapira, H., and Catt, K. 1992. Cloning and expression of a novel angiotensin II receptor subtype. J. Biol. Chem. 267:9455-9458.

4. Iwai, N., and Inagami, T. 1992. Identification of two subtypes in the rat type I angiotensin receptor. FEBS Lett. 298:257-260.

5. Elton, T., et al. 1992. Isolation of two distinct type I angiotensin receptor genes. Biochem. Biophys. Res. Commun. 184:1067-1073.

6. Sasamura, H., et al. 1992. Cloning, characterization, and expression of two angiotensin receptors (AT-1) isoforms from the mouse genome. Biochem. Biophys. Res. Commun. 185:253-259.

7. Kitami, Y., Okura, T., Marumoto, K., Wakamiya, R., and Hiwada, K. 1992. Differential gene expression and regulation of type-1 angiotensin II receptor subtypes in the rat. Biochem. Biophys. Res. Com mun. 188:446-452.

8. Burson, J., Aguilera, G., Gross, K., and Sigmund, C. 1994. Differential expression of angiotensin receptor $1 \mathrm{~A}$ and $1 \mathrm{~B}$ in mouse. Am. J. Physiol. 267:E260-E267.
9. Konishi, H., Kuroda, S., Inada, Y., and Fujisawa, Y. 1994. Novel subtype of human angiotensin II type 1 receptor: cDNA cloning and expression. Biochem. Biophys. Res. Commun. 199:467-474.

10. Ito, M., et al. 1995. Regulation of blood pressure by the type $1 \mathrm{~A}$ angiotensin II receptor gene. Proc. Natl. Acad. Sci. USA. 92:3521-3525.

11. Chen, X., et al. 1997. Targeting deletion of angiotensin type $1 \mathrm{~B}$ receptor gene in the mouse. Am. J. Physiol. 272:F299-F304.

12. Lenkei, Z., Corvol, P., and Llorens-Cortes, C. 1995. The angiotensin receptor subtype AT1A predominates in rat forebrain areas involved in blood pressure, body fluid homeostasis, and neuroendocrine control. Mol. Brain Res. 1:53-60.

13. Johren, O., Inagami, T., and Saavedra, J. 1995. AT1A, AT1B, and AT2 angiotensin II receptor subtype gene expression in rat brain. Neuroreport. 6:2549-2552.

14. Kakar, S., Riel, K., and Neill, J. 1992. Differential expression of angiotensin II receptor subtype mRNAs (AT1-A and AT1-B) in the brain. Biochem. Biophys. Res. Commun. 185:688-692.

15. Oliverio, M., et al. 1998. Reduced growth, abnormal kidney structure, and type 2 (AT2) angiotensin receptor-mediated blood pressure regulation in mice lacking both AT1A and AT1B receptors for angiotensin II. Proc. Natl. Acad. Sci. USA. 95:15496-15501.

16. Koller, B., and Smithies, O. 1992. Altering genes in animals by gene targeting. Annu. Rev. Immunol. 10:705-730.

17. Davisson, R., et al. 1998. The brain renin-angiotensin system contributes to the hypertension in mice containing both the human renin and human angiotensinogen transgenes. Circ. Res. 83:1047-1058.

18. Rowland, N., and Fregly, M. 1993. Brain angiotensin AT-2 receptor antagonism and water intake. Brain Res. Bull. 32:391-394. 